\title{
ASPERGILLUS ROOT-STALK ROT OF SANSEVIERIA (SANSEVIERIA LAURENTII, WILDEM)
}

\author{
L. A. Alvarez García ${ }^{1}$ \\ and \\ Miguel A. DÍAZ ${ }^{2}$

\section{INTRODUCTION}

The ocurrence in Puerto Rico of a serious root-stalk disease of Sansevieria Laurentii, Wildem, a bud variation of the common species S. Zeylanica Wildd. (Bowstring hemp), has been found to hamper the exportation of slips to the United States market.

The disease hindered the exportation of this crop to such an extent, that Puerto Rican nurserymen requested technical help from the Agricultural Experiment Station and from the Agricultural Extension Service of the University of Puerto Rico.

The outcome of the technical findings is presented here as a contribution to the knowledge of ornamental plant diseases in Puerto Rico and their control.

\section{ECONOMIC IMPORTANCE}

Sansevieria plants are highly esteemed as house plants. They are characterized by a beautiful yellow band bordering the edge of the leaf blade. It is claimed that the plants are very hardy and well adapted to a great variety of environmental conditions, thriving even in extreme dry or wet conditions and under low or high light intensity.

During the early part of this century, the exportation of Sansevierias to the United States market was of relatively economic importance. The year 1920 was a boom year, but a gradual decline was then felt until 1930, when a new fad for Sansevierias revived the local industry. Then in 1936, a marked drop in exportations was felt, due to a preference for desert plants, principally from California. The local nurserymen looked for new markets and exported their crop to England, France and Belgium.

1 Plant Pathologist, Agricultural Experiment Station, Río Piedras, P. R.

2 Assistant Horticulturist, Agricultural Extension Service, Río Piedras, P. R. 
During the Second World War exportation of Sansevierias to the United States received great attention. At present there is a great demand for the crop.

\section{SYMPTOMS OF THE DISEASE}

Aspergillus root-stalk rot, following spontaneous or artificial infection of wounded tissues of slips of Sansevierias, is characterized by a rapid invasion of the succulent tissues of the rootstalk and leaf petioles. The slips are obtained usually by cutting, but sometimes by "snapping" the brittle stems. The slips which are snapped off are known as "knock-off" slips.

Injured infected tissues become water-soaked and permeated by the profuse mycelial growth of the causative fungus. Once the parasite has gained a foothold, its growth and invasion of the host tissues is very rapid. The epidermal tissues of the root-stalk usually keep their firmness even in cases of advanced rotting of the inner tissues.

In a warm, humid environment, the percentage of diseased slips is very great, and the amount of infections is very high. In such an environment the parasite works rapidly, causing a complete rot of the root-stalk in a few days. This correlates with the behavior of the parasite when grown in artificial substrates in a warm, humid environment.

Rotting of the root-stalk advances a long way up the stalks, the leaf petioles are invaded, and the result is the abscission of the diseased leaves. Infected tissues of Sansevieria plants appear moldy and covered with a profuse superficial mycelium, which spreads readily developing masses of black spores.

\section{THE CAUSAL AGENT}

The black-mould fungus responsible for the root-stalk rot and leaf of Sansevierias belongs to the Aspergillaceae. Microscopic examination revealed it to be Aspergillus niger van Tiegham.

In Puerto Rico the senior author has found $A$. niger causing decay of garlic (Allium sativum) in storage. A. niger has been reported from Brazil, by Viegas, ${ }^{10}$ causing bulb rot of onions (Allium cepa L.). A. niger has also been reported causing fruit decay of apples, cotton bolls, corn, and potato tubers. ${ }^{6,}$ s, 9, 12

The $A$. niger, responsible for the root-stalk of Sansevierias in Puerto Rico, is favorably influenced under high humidity and high temperatures, to parasitize wounded, succulent tissues of 
these plants. The fungus grows readily in darkness and in few days covers the surface on most artificial media in Petri dishes.

On potato-dextrose-agar, with a $\mathrm{pH}$ value of $6.15, \mathrm{~A}$. niger covered completely the $9 \mathrm{~cm}$. plate in 4 days, when incubated in a constant temperature range from 25 to $40^{\circ} \mathrm{C}$. No growth was obtained at temperatures below $10^{\circ} \mathrm{C}$., or above $45^{\circ} \mathrm{C}$.

Curve showing growth-temperature relations of Aspergillus niger van Tieghen grown on potato dextrose-agar at constant temperatures for five days.

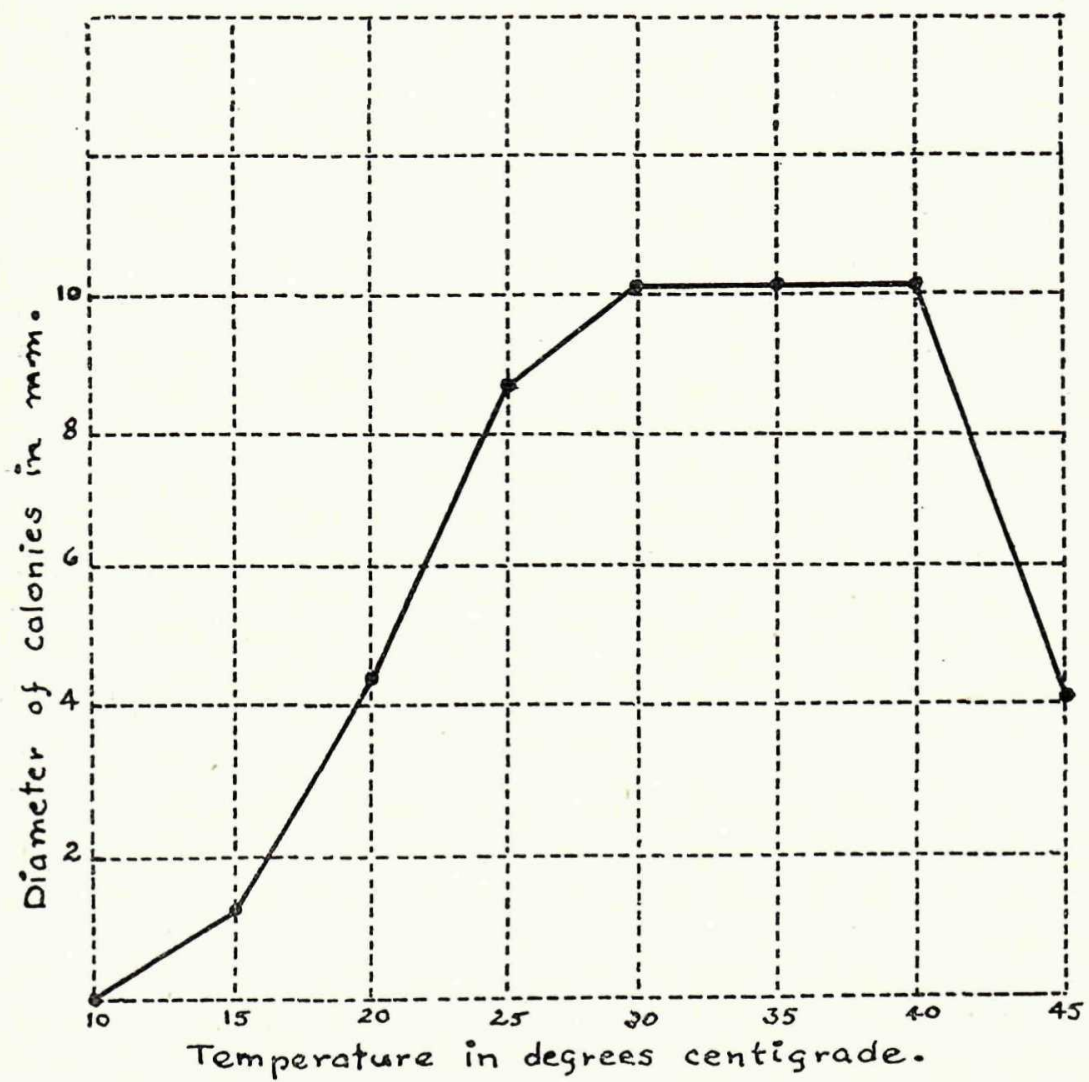

Sporulation was very profuse at all temperatures from 25 to $40^{\circ} \mathrm{C}$. The organism was found to grow within a very wide $\mathrm{pH}$ range, from $\mathrm{pH} 2$ to $\mathrm{pH} 8$. No efforts were made to determine the limits of growth on the acid or alkaline side of the range. Growth was rapid in media with a high water content. 


\section{EPIDEMIOLOGY}

Slips of Sansevierias, as prepared for shipment, bear from 3 to 5 leaves, and have an approximate perpendicular length of 10 to 12 inches. When the slips are cut or snapped off from the stock plant, a profuse bleeding from the wounded root-stalk occurs.

Parasitism by $A$. niger seems to occur only through wounds on the root-stalk or leaf petioles, as confirmed by artificial inoculation of wounded and unwounded tissues.

Aspergillus root-stalk rot appeared in slips shipped during the summer and winter months. A warm environment with insufficient ventilation keeps the slips warm and moist. These are important factors associated with the serious damages reported on shipped Sansevierias.

The material for winter shipment was prepared as follows:

(1) Pairs of slips were wrapped in newspaper. (2) Ten such pairs were wrapped in newspaper to form a bundle. (3) The bundles were placed in wooden boxes lined with newspaper. After these operations the bundles were ready for ship. ment.

Shipments of Sansevierias took about 10 days to reach the mainland.

During the summer, the slips are not wrapped in so much paper, nevertheless, great damages are reported in transit, due to root-stalk rot.

\section{CONTROL}

The remarkable performance of a number of recently developed synthetic organic compounds for the prevention of plant diseases, suggested the testing of some of them in an attempt to find an effective and practical control measure for the prevention of the aspergillus root-stalk rot of Sansevierias.

The following organic and inorganic compounds were tested: Spergon, Semesan, Semesan Jr., Dubarry 1155, Arasan, Zinc oxide, cuprous oxide, copper carbonate, mercuric bichloride, boric acid and paraffin.

\section{TECNIQUE FOR MEASURING EFFECTIVENESS}

The fungicidal value of the organic and organic compounds under consideration was determined on the basis of the number of diseased slips treated and on the number and the degree of invasion and rotting of the infected tissues of the root-stalks. 
Preliminary work consisted in the treatment of lots of ten pairs of lips, immediately after being cut off from the stock plants, with the fungicidal dusts, or immersed in the solutions. The wounded tissues of the root-stalks were dressed or immersed in the solutions, as the case demanded.

The slips were treated and wrapped for shipment and packed in wooden boxes as if they were to be exported. The treated and packed slips were stored in a dark room and left for 10 days in order to observe the effectiveness of the treatments in conditions similar to those liable to occur in shipments.

The results observed in the experiments conducted during the month of December 1945 and January 1946 are summarized below:

\section{DIPPING}

Mercuric bichloride: Slips were inmersed in a 1-1000 bichloride solution for 3 minutes and immediately afterward were washed thoroughly with water, so as to remove the residual salt. It proved very effective. This treatment, however, had the disadvantage of being laborious and expensive. Moreover, there was no objective way of detecting treated from untreated slips, which is a handicap if we consider that the worker can make mistakes easily.

Mercuric bichloride without water washing: The previous technique was followed but not water washings were performed. The results were discouraging. Probably because residual salt injured the tissues, which eventually rotted.

Benzoic acid solution (3 percent in 30 percent alcohol): Tissue injury and rapid decay occured when Sansevieria slips were treated with this solution.

Paraffin $\left(50\right.$ to $\left.60^{\circ}\right)$ : This treatment ẉas ineffective and expensive.

\section{DUSTING}

Spergon:

This treatment proved very effective by checking the disease completely. The ease in operation and the yellow color of the fungicide on treated slips made it most desirable.

Semesan Jr.:

It was very effective, however there was no significant difference in its effectiveness when compared with Spergon, or the bichloride-washing treatment. 


\section{Semesan:}

Fairly good. It controlled the disease up to 50 percent.

Zinc Oxide:

Ineffective.

Corona Coppercarb:

Ineffective.

Cuprous Oxide:

Ineffective.

Results of these treatments are presented in Table 1.

TABle No 1-TESTING FUNGICIDAL CHEMICALS FOR CONTROL OF SANSEVIERIA (Sansevieria Laurentii WILDEM), ASPERGILLUS ROOT-STALK ROT

Slips kept after treatment in a dark room at $30^{\circ} \mathrm{C}$. for 10 days.

\begin{tabular}{|c|c|c|c|}
\hline No. & Trade Name & Treatment & $\begin{array}{l}\text { Percent } \\
\text { of } \\
\text { Effect- } \\
\text { iveness }\end{array}$ \\
\hline & Corrosive Sublimate... & Mercuric bicholride with thorough washings..... & 100 \\
\hline & Spergon................ & Tetrachloro benze-quinone. & 100 \\
\hline $3 \ldots$ & Semesan Jr................ & Ethyl-mercury-phosphate $1 \% \ldots \ldots \ldots \ldots \ldots \ldots$ & 100 \\
\hline & Semesan ...... & Hydroxy-mereury-chlorophenol $30 \% \ldots \ldots \ldots$ & 50 \\
\hline & Zine Oxide... & 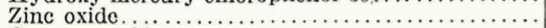 & 10 \\
\hline $6 \ldots$ & Cuproxide... & 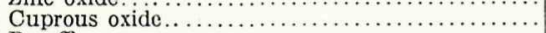 & 10 \\
\hline & Paraffin.............. & 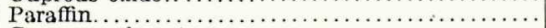 & 10 \\
\hline & Corona Coppercarb.... & 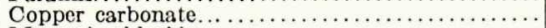 & 10 \\
\hline & Corrosive Sublimate.......... & Mercuric chloride.............................. & 0 \\
\hline $10 \ldots$ & Benzoic Acid................. & Benzoic acid $3 \%$ in $30 \%$ alcohol....................... & 0 \\
\hline
\end{tabular}

The data in Table 1 show the effectiveness of Spergon, Semesan Jr., and mercuric bichloride with water washings in controlling aspergillus root-stalk rot.

The non-phytotoxicity and the bright yellow color of Spergon, which made recognition of the treated slips easy, and its good adhesiveness were considered in selecting it for the final shipping test.

On January 3rd and 4th, 1946, twenty-thousand slips were treated with Spergon, then they were prepared for shipment, as previously explained, and sent to New York in two lots of tenthousand each. The report of their arrival free from aspergillus root-stalk rot, demonstrated the effectiveness of the Spergon treatment. 'Untreated checks also shipped, and those kept for 10 days in storage in Puerto Rico, rotted badly.

\section{CONCLUSION AND SUMMARY}

The results of the experiments conducted at $\mathrm{Mr}$. Charles Pennok's farm in Río Piedras, (North and South nurseries) during the two-month period from December 1945 to January 
1946, to find an effective commercial control for aspergillus rootstalk rot of Sansevieria, revealed the practical fungicidal value of Spergon, Semesan Jr. and bichloride of mercury; the latter followed by thorough washings.

Dusting with Spergon and Semesan Jr. is easy and inexpensive. Spergon, which is easily recognized in treated cuttings by its yellow color, was finally selected for the commercial treatment of Sansevierias slips prior to shipping.

This treatment of root-stalk cuttings also lessens considerably decay in seed beds. It can be used either in powder form or in water suspension. 


\section{LITERATURE}

1. Anonymous_A $\$ 10,000,000$ nursery business. The Economic Review. The camber of Commerce of Puerto Rico. Vol. IV, No. 4, September 1939.

2. Barss, H. P.-Reducing losses from diseases and pests. United States Dept. Agr. (Reprint from Rept. Agr. Expt. Sta. 1944).

3. Belle, I.-Alteration des grains de café produites par des Aspergillus. Proc. Soc. Phys. et Nat. Bordeaux 1912-13: 37-38. 1913.

4. Cook, H. T.-Summary of results from cooperative seed treatment tests with beets, cabbage, celery, cucumbers, lettuce, peas, spinach and sweet corn in 1941. The Extension Pathologist serial No. 47, 1942.

5. Coulter, J. W.-La piña. Unión Panamericana Oficina de Cooperación Agrícola. Julio 1940.

6. Layton, D. V.-Control of sweet-potato stem rot (Abstract). Phytopathology 20 (1) : 116-17. 1930.

7. Leclerg, E. L., Clayton, C. N., and Eddins, A. H.-Report of the sub-committee on the control of Irish potato diseases of war service committee of the American Phytopathological Society. February 20, 1943.

8. Machacek, J. E.-The black Mould of Onions, caused by Aspergillus Niger, v. Tiegh, Phytopathology 19 (8) : 733-739, 1929.

9. Taubenhaus, J. J.-A study of the black and yellow moulds of car corn. Texas Agric. Expt. Sta. Bul. 270, 1920.

10. Viegas, A. P.-Algunos fungos do Brasil. 11. Ascomicetos. Bragantia, 4 (1-6): 7, 1944.

11. Walker, J.C. and Murphy A.-Onion bulb decay caused by Aspergillus allianceus. Phytopathology, 24 (3) : 289-291, 1934.

12. Wayne Van Pelt-A new fungous disease causing serious damage in storage houses. Ohio Agr. Exp. Sta. Monthly Bul. 1: 152-156. 1917.

13. - Onion diseases as found in Ohio. Ohio Agr. Exp. Sta. Monthly Bul. 3: 70-76, 1919. 